\title{
Anti-TNF antibody treatment of Crohn's disease
}

\author{
S J H van Deventer
}

Crohn's disease and ulcerative colitis are the two idiopathic chronic inflammatory bowel diseases. Although these diseases may show substantial phenotypic overlap, it is widely accepted that these represent distinct pathogenic entities. The cause of neither ulcerative colitis nor Crohn's disease is known, and genetic as well as environmental factors have been implicated. Previous reports implicating single microbial pathogens (Mycobacterium paratuberculosis, measles) in Crohn's disease are controversial and have not been confirmed. ${ }^{1-11}$ On the other hand, evidence that antigen driven ill controlled activation of mucosal $\mathrm{T}$ lymphocytes is a major disease mechanism has accumulated in recent years, and this has led to novel therapeutic strategies. I here review the clinical results of anti-TNF antibody treatment against the background of current knowledge of the regulation of mucosal immune activation.

\section{Current treatment of Crohn's disease is insufficient}

The incidence of Crohn's disease is increasing in Western Europe and the USA, and is now $6-10 / 100000$ inhabitants. ${ }^{12}{ }^{13}$ Because Crohn's disease is a lifetime disorder, the prevalence is at least 20 -fold higher. The clinical symptoms and signs of Crohn's disease can be rather nonspecific, including abdominal pain, weight loss, fatigue and (bloody) diarrhoea, but most patients with active disease have an increased erythrocyte sedimentation rate (ESR) or raised circulating $\mathrm{C}$ reactive protein concentrations. Although commonly known as "terminal ileitis", only about $30 \%$ of patients have disease restricted to the terminal ileum, and most patients have isolated large bowel, or combined small and large bowel involvement. The disease may also involve the oral cavity, oesophagus and stomach, and can occur outside the intestinal tract, in particular in the perineal area (histologically characterised by granulomatous lymphangitis) or located in surgical wounds. About $20 \%$ of patients have perianal fistulas, and the presence of such lesions is a substantial risk factor for eventual complete loss of the large bowel and construction of a permanent ileostoma. ${ }^{14}$ Lifestyle factors may have an important impact on disease activity, and smoking of cigarettes worsens disease activity and leads to frequent relapses (interestingly, in ulcerative colitis smoking is protective). ${ }^{15-17}$

Overall survival of Crohn's disease patients is not different from controls, but about $70 \%$ of all patients undergo one or more surgical procedures in the course of disease, $25 \%$ of patients with large bowel involvement eventually end with a permanent ileostoma, and despite current medical treatment, a cross sectional population based study indicated that
$30 \%$ of patients have active disease. ${ }^{18}{ }^{19}$ Medical treatment of Crohn's disease consists of administration of high dose mesalazine in mild cases, corticosteroids in moderate to severe disease, and immunosuppressives, in particular azathioprine and methotrexate for patients with corticosteroid dependent or corticosteroid refractory disease. ${ }^{20}{ }^{21}$ After initial enthusiasm, several studies have failed to confirm a treatment benefit of oral cyclosporine, and the use of this drug is now restricted to complicated fistulas or extra-intestinal disease..$^{22-25}$ None of the aforementioned drugs is the ideal therapeutic reagent. Mesalazine is relatively non-toxic and well tolerated, but the ability to induce remissions is limited and a recent meta analysis failed to demonstrate a maintenance effect. ${ }^{26}$ Corticosteroids are effective and continue to be the mainstay of treatment for patients with active Crohn's disease, but are associated with many side effects. Moreover, corticosteroid treatment fails to induce remissions in $20-30 \%$ of patients, and a substantial percentage of patients become corticosteroid dependent. ${ }^{27}$ Budesonide is a glucocorticoid with a very high affinity for the glucocorticoid receptor, and is effective in inducing remissions while have significantly reduced systemic side effects as a result of effective first-pass liver metabolism. ${ }^{28-30}$ However, no formulation has been demonstrated to effectively deliver budesonide to the large bowel, and no corticosteroid, including budesonide, effectively maintains remissions. ${ }^{31}{ }^{32}$ Azathioprine has been long used in Crohn's disease and is relatively safe: about $7 \%$ of patients develop side effects and another $7 \%$ infectious complications (in particular viral infections)..$^{33-36}$ The main place in the therapeutic arsenal is treatment of corticosteroid refractory or corticosteroid dependent patients, and treatment of fistulas. Although azathioprine has an important place in the therapeutic repertoire in Crohn's disease, the response to treatment is slow, a significant percentage of patients do not respond to treatment, and five to six patients need to be treated to prevent a single relapse. ${ }^{36}$ Methotrexate is widely used in Crohn's disease (at rather high doses: 15-25 mg/week), and has been shown to be effective in allowing discontinuation of corticosteroid treatment in refractory patients. ${ }^{3738}$ However, the long term efficacy of methotrexate in Crohn's disease is not known, and therapeutic efficacy tends to decrease during prolonged administration.

One of the major problems with current medical treatment is the inability to change the natural course of disease. After successful medical induction of remission, $60-70 \%$ of patients experience a relapse within 12 months. ${ }^{31} 39$ Large bowel resections are also 
associated with a high relapse rate, and (asymptomatic) ulcerations of the surgical anastomosis are frequently observed 3-12 months after ileocaecal resection. ${ }^{40}{ }^{41}$ Fortunately, the rate of clinical relapses after this latter procedure is much lower and amounts to about $50 \%$ after five years. ${ }^{42}$ Finally, it remains unknown what the preferred treatment strategy is in Crohn's disease. There are no data to indicate that the historical step up approach, starting with mesalazine and adding corticosteroids and immunosuppressives, is superior to immediate treatment with immunosuppressives or vice versa, nor is it known whether the choice of initial treatment changes the long term outcome of the disease.

The immune defect of Crohn's disease A common lesion observed early in Crohn's disease is the aphtoid lesion, a small ulcer that originates from mucosal lymphoid aggregates that are scattered throughout the bowel. These lymphoid aggregates are covered by a specialised type of epithelial cells, named $M$ cells that are involved in the processing of gut lumen antigens. ${ }^{43}{ }^{44}$ Later in the course of disease a more general and transmural activation of lamina propria and submucosal $\mathrm{T}$ lymphocytes is observed, but even in patients with severe disease this is poorly reflected in the peripheral blood. The inflamed mucosa also shows an influx of granulocytes and activated monocytes, which produce significant amounts of eicosanoids, cytokines and chemokines. The mononuclear cells may be organised in granulomas, which are considered a hallmark of Crohn's disease. In progressive disease the aphtoid lesions progress to ulcers, which may coalesce to form longitudinal "railroad" tracks that may run along the entire length of the large bowel. Strictures may form at sites of extensive inflammation, and are frequently observed at surgical anastomoses. With the exception of transmural inflammation and the occurrence of granulomas, the histological features of Crohn's disease tend to be non-specific and of little help in establishing a diagnosis. Recently however, specific changes of $\mathrm{T}$ lymphocyte function and cytokine patterns have been recognised that distinguish Crohn's disease from other inflammatory bowel disorders (see below).

A major breakthrough in the insight into the pathogenesis of Crohn's disease was a result of a series of - rather serendipitous - findings in mice with various (induced) defects of $\mathrm{T}$ lymphocyte function (reviewed in references ${ }^{45-48}$ ). In addition, $\mathrm{T}$ lymphocyte transfer models form Balb/C into SCID mice have yielded pivotal results that will be briefly summarised here. When $\mathrm{CD} 4^{+} \mathrm{T}$ lymphocytes are transferred from normal Balb/C mice into SCID mice, various organs including the small and large bowel mucosa become repopulated with donor cells, without initially causing disease, but when only a subpopulation of naïve cells $\left(\mathrm{CD} 4^{+} \mathrm{CD} 45 \mathrm{RB}^{\text {high }}\right)$ is transferred, the recipient mice develop inflammatory disease of the large bowel (and of the stomach). This disease is characterised by Th1 biased production of lamina propria ( $\mathrm{T}$ lymphocyte) cytokines. Interestingly, co-transfer of the $\mathrm{CD} 4{ }^{+} \mathrm{CD} 45 \mathrm{RB}^{\text {low }}$ population prevents development of disease, and disease does not occur in germ free animals. ${ }^{49-51}$ Moreover, it has been demonstrated that a high IL10 producing $\mathrm{T}$ cell population (called $\operatorname{Tr} 1$ ) was able to prevent CD $4{ }^{+} \mathrm{CD} 45 \mathrm{RB}^{\text {high }}$ transfer colitis. ${ }^{52}{ }^{53}$ Hence, in this model, disease can be caused by a subpopulation of CD4+ T lymphocytes, which are controlled by another CD4+ subpopulation. ${ }^{545}$ IL10 seems to be one of the important regulatory cytokines in this model, and the initiation of disease is antigen dependent. Therefore, the key players in immune mediated inflammation in the gut mucosa are intestinal (bacterial) antigens, reactive $\mathrm{T}$ lymphocytes, and regulatory $\mathrm{T}$ lymphocytes.

Initial studies on mucosal cytokine (IL1 $\beta$, IL6, IL8) expression did not clearly distinguish Crohn's disease from ulcerative colitis or infectious colitis, but more recent data allow the conclusion that Crohn's disease is a Th1 biased condition. As compared with various controls (normal subjects, ulcerative colitis patients) increased expression of IL12 and IL18 by lamina propria mononuclear cells has been reported in Crohn's disease, and lamina propria $\mathrm{T}$ lymphocytes produce more IFN $\gamma .{ }^{56-58}$ Increased TNF $\alpha$ expression occurs both in Crohn's disease and in ulcerative colitis, but the distribution of the source cells differs: only in Crohn's disease cells located in the deep lamina propria and submucosa produced $T N F \alpha^{59}{ }^{60}$ In addition, lamina propria $\mathrm{T}$ lymphocytes from Crohn's disease patients show increased IL2 dependent proliferation, and are relatively resistant to apoptosis induced by CD2 activation, IL2 depletion or engagement of Fas. ${ }^{61}{ }^{62}$ This phenomenon is in part explained by an increased ratio of intracellular expression of the proteins Bax (pro-apoptotic) and Bcl-2 (anti-apoptotic; see below). It should be noted that apoptosis resistance is not caused by mucosal inflammation in itself because it is not observed in ulcerative colitis. ${ }^{62}$

How can these results be translated in clinically effective treatment strategies? Theoretically, multiple strategies would be expected to be effective, including (1) a reduction of the antigenic pressure within the gut lumen, (2) interference with proliferation of activated $\mathrm{T}$ lymphocytes, (3) interference with transcription of the genes encoding pro-inflammatory cytokines, prevention of release of cytokines by inflammatory cells, or neutralisation of released cytokines, (4) administration of counterregulatory cytokines. Indeed there is evidence that conventional treatment modalities owe their efficacy to interference with these mechanisms. For example, reduction of the gut luminal antigenic pressure by surgical faecal diversion, or administration of antibiotics is known to decrease the activity of Crohn's disease and re-introduction of faeces in the diverted bowel loop frequently leads to an exacerbation of disease. ${ }^{6364}$ Azathioprine, methotrexate and mycophenolate mofetil are though to owe their beneficial effects to inhibition of lymphocyte 
proliferation, and prednisone interferes with cytokine transcription. More importantly, a wide range of novel intervention strategies has been based on these principles, including inhibitors of cytokine gene transcription, inhibitors of cytokine releasing enzymes, administration of recombinant human IL10, and neutralisation of pro-inflammatory cytokines. ${ }^{65-73} \mathrm{I}$ will here focus on $\mathrm{TNF} \alpha$ neutralising strategies, with particular emphasis on their mode of action.

\section{TNF $\alpha$ blocking strategies}

The production of $\mathrm{TNF} \alpha$ is tightly regulated at the transcriptional, translational and posttranslational levels, providing many opportunities for therapeutic intervention. Increase of the intracellular CAMP concentration reduces the TNF transcription rate, and this is the mechanism by which noradrenaline (norepinephrine), pentoxifylline and, in part, thalidomide reduce TNF $\alpha$ transcription. ${ }^{74-80}$ Another approach is to inhibit the nuclear translocation of the transcription factor NFKB that is important for the transcription of multiple cytokine genes including $\mathrm{TNF} \alpha$. After translation, the $\mathrm{TNF} \alpha$ protein needs to be proteolytically cleaved at the cell membrane, to be released as the homotrimeric soluble mature TNF $\alpha$. Uncleaved TNF remains membrane bound, and is biologically active by engaging the p75 TNF receptor in cell to cell interactions. Cleavage of $\mathrm{TNF} \alpha$ is caused by a specific metalloproteinase inhibitor ( $\mathrm{TNF} \alpha$ converting enzyme-TACE) and can be inhibited by specific metalloproteinase inhibitors. ${ }^{81} 82$ Finally, antibodies and soluble TNF receptor proteins can bind and neutralise soluble TNF $\alpha$, and some also recognise membrane bound $T N F \alpha$. It should be noted that important differences exist in the biological effects as well as the clinical efficacy (as far as has been tested) of these different approaches. Oxpentifylline (a pentoxifylline analogue) did not change the activity of Crohn's disease although it reduced the production of $\mathrm{TNF} \alpha$ by ex vivo stimulated monocytes, indicating that either targeting of membrane bound TNF $\alpha$ is of pivotal importance or that $\mathrm{TNF} \alpha$ production by cells other than monocytes (that is, $\mathrm{T}$ lymphocytes) should be targeted. ${ }^{83}{ }^{84}$ Various inhibitors of $\mathrm{NF} \kappa \mathrm{B}$ are currently being evaluated in animal models of inflammatory bowel disease, and some have shown efficacy. ${ }^{65}{ }^{85}$ However, inhibition of NFкB is not synonymous with TNF $\alpha$ inhibition, and may have complex effects on $\mathrm{TNF} \alpha$ induced biological effects, such as apoptosis. Known NFKB inhibitors, such as aspirin, do not reduce disease activity of Crohn's disease, but indeed may induce severe flares. TACE inhibitors may effectively release of TNF $\alpha$ by monocytes and lymphocytes, in vitro as well as in vivo, but do not change the expression of membrane bound $\mathrm{TNF} \alpha$ that is important in interactions of immune cells. Finally, even monoclonal antibodies and TNF receptor constructs may have different biological activities: monoclonal anti-TNF $\alpha$ antibodies are specific for $T N F \alpha$, but designer molecules using the p75 $\mathrm{TNF}$ receptor also bind lymphotoxin, which is importantly involved in humoral immune responses.

In conclusion, the biological effects of various $T N F \alpha$ inhibiting strategies importantly differ, and results obtained with a certain (class of) inhibitors cannot be simply extrapolated to other reagents. The determinants of the clinical efficacy of TNF inhibiting strategies are only partly known, and need to be studied in more detail.

\section{TNF $\alpha$ antibodies in Crohn's disease}

The first Crohn's disease patient to be treated with anti-TNF $\alpha$ antibody (infliximab) was a young girl with severe Crohn's colitis, refractory to treatment including prednisone and azathioprine. ${ }^{86}$ She received two infusions of the antibody at a dose of $10 \mathrm{mg} / \mathrm{kg}$, within two weeks, and the results were remarkable: within a few days stool consistency and frequency normalised, the ESR decreased, and the extensive intestinal ulceration healed. Eventually she relapsed, and after undergoing several surgical procedures now has a permanent ileostoma. Encouraged by this initial result, a small uncontrolled pilot study in 10 patients with treatment refractory Crohn's disease was performed, and eight of nine evaluable patients (one patient underwent surgery rapidly after the infusion) showed a dramatic response after infusion of a single infliximab dose of 10 (eight patients) or 20 (two patients) $\mathrm{mg} / \mathrm{kg} .{ }^{87}$ The effects of treatment were rapid (within days), increased serum $C$ reactive protein and secreted phospholipase $\mathrm{A}_{2}\left(\mathrm{sPLA}_{2}\right)$ concentrations rapidly reduced in all patients and intestinal ulcerations healed. ${ }^{87} 88$ This latter observation was remarkable, because no other drug treatment had been demonstrated to effectively heal the primary lesion (the mucosal ulcer) of Crohn's disease. The first controlled clinical trial using infliximab included 108 patients who were randomised to receive infliximab (5 or $10 \mathrm{mg} / \mathrm{kg}$ ) or placebo. ${ }^{89}$ Non-responders were offered an open label infusion of infliximab $(10 \mathrm{mg} / \mathrm{kg})$ and all eventual responders were re-randomised to receive infliximab $(10 \mathrm{mg} / \mathrm{kg})$ or placebo every eight weeks. The results of this study showed that infliximab treatment induced significantly more therapeutic responses and complete clinical remissions as compared with placebo (infliximab $5 \mathrm{mg} / \mathrm{kg}$ : $81 \%$; placebo $17 \%$ ) and that these therapeutic responses could be maintained by repeated administration of the antibody during the 44 week follow up period. ${ }^{90}$ Endoscopies performed in a subgroup of patients in this study demonstrated a clear mucosal healing effect, which correlated with the reduction of the clinical disease severity score. ${ }^{91}$ Some patients with perianal fistulas experienced remarkable healing in the course of the study, and this prompted initiation of a separate trial to investigate the efficacy of infliximab for this indication. Patients with fistulas secondary to Crohn's disease are commonly treated with immunosuppressive drugs (azathioprine and cyclosporine) and antibiotics, but apart from anecdotal reports, no medical treatment had been evaluated in a 
controlled clinical trial. Few reliable data on the efficacy of surgery for fistulas are available, but the results are so disappointing that most surgeons refrain from curative surgery and only perform drainage procedures. Ninety four patients were included in the controlled clinical infliximab trial for perianal fistulas and were infused with infliximab (5 or $10 \mathrm{mg} / \mathrm{kg}$ ) or placebo at 0,2 and 6 weeks. ${ }^{92}$ The primary end point was healing (no spontaneous or induced drainage from the external fistula opening at two or more visits) of $50 \%$ or more of the fistulas. In significantly more infliximab treated patients drainage from the fistulas stopped, and in some patients external openings disappeared completely (infliximab $5 \mathrm{mg}$ : 68\%; placebo $26 \%$ ). Moreover, the time to reach the end point was significantly shorter in infliximab treated patients than in the placebo (that is, conventionally treated) group (14 versus 40 days). Infliximab has also been used to treat a small number of patients with extraintestinal-“metastatic"-Crohn's disease. In two young women extensive and debilitating ulcerations of the perineal area responded very well to treatment, and the ulcers remained closed (both patients received cyclosporine treatment after the infliximab infusion). ${ }^{93}$

Infliximab was approved for clinical use in active Crohn's disease in the USA in the autumn of 1998, and received a positive advice for the European Medicines Evaluation Agency in May 1999. One of the major issues involved in approval was safety. Infusion reactions occur in about $6 \%$ of patients, which is comparable with the rate of infusion reactions associated with immunoglobulins or other monoclonal antibodies, and are usually not severe. In most patients infusions can be continued at a slower rate or after administration of an antihistamine. Infliximab is mouse/human chimeric antibody and human-anti-chimeric antibodies are induced in $13 \%$ of patients, and are associated with a slightly higher rate of infusion reactions upon re-infusion (data on file, Centocor). Some patients that were re-infused more than two years after the first infusion developed very high HACA titres, and this was associated with systemic symptoms and signs of serum sickness. However, no complement consumption or endorgan damage occurred, and the symptoms reacted well to corticosteroids or antihistamines (data on file, Centocor). High titre HACAs do neutralise infliximab and therefore strongly interfere with therapeutic efficacy. To date, no definitive advice can be given concerning the prevention of HACA development, although there are indications that simultaneous treatment with immunosuppressive drugs lowers the HACA rate. Development of malignancies is a major complication of most immunosuppressive drugs, but at present the incidence of neither lymphomas nor solid tumours was found to be increased in infliximab treated patients (data on file, Centocor). It should be noted that the follow up period of most treated patients is still short, and a post-treatment surveillance programme has been instituted. $\mathrm{TNF} \alpha$ is important for clearing microbial pathogens and $\mathrm{TNF} \alpha$ deficient mice are very susceptible to intracellu- lar bacterial pathogens. However, when corrected for a similar follow up period, the incidence of infectious complications in infliximab treated patients does not seem to be higher as compared with placebo infused patients, with the exception of a slightly higher rate of upper respiratory infections (data on file, Centocor). Finally, anti-dsDNA antibodies were found in a small percentage of infliximab treated Crohn's disease patients. These antibodies tend to be of low titre, disappear in most patients, and are not associated with symptoms of autoimmune disease. It is possible that induction of anti-dsDNA antibodies is a direct result of the biological activity of infliximab (see below) and therefore should be regarded as an "effect" rather than a "side effect".

The clinical experience with other $\mathrm{TNF} \alpha$ binding molecules in Crohn's disease is less extensive. A humanised antibody, CDP571, was found to have short-term clinical efficacy in patients with active Crohn's disease, and follow up clinical studies are ongoing. ${ }^{94}$ Completely human TNF binding antibodies, and p55 receptor molecules are currently in (pre)clinical development for Crohn's disease.

\section{How do anti-TNF $\alpha$ antibodies work?}

$\mathrm{TNF} \alpha$ is a potent pro-inflammatory cytokine that is able to induce a wide range of secondary inflammatory cascades in humans. Many of these biological effects, including the induction of cytokines, chemokines and adhesion molecules, activation of the coagulation and complement cascades, and induction of HLA-class II molecules on the intestinal epithelium are important for mucosal inflammation in Crohn's disease (for review see van Deventer ${ }^{95}$ ). On the other hand, many other potent pro-inflammatory cytokines (IFN $\gamma$, IL1 $\beta$ ) are induced in the inflamed intestinal mucosa, and it is somewhat surprising that neutralisation of $\mathrm{TNF} \alpha$ alone has such potent clinical effects. Clinical observations indicate that infliximab acts very rapidly (decreases of $\mathrm{C}$ reactive protein concentration are already observed within days after infusion), and the effects of a clinical infusion are sustained for 10-12 weeks in most patients. In part, these prolonged clinical effects may be explained by the pharmacokinetics of the antibody, but data on infliximab tissue concentrations are not available, precluding a definitive conclusion. In view of the pivotal role of $\mathrm{CD} 4^{+} \mathrm{T}$ lymphocytes in Crohn's disease, we have focused on the effects of infliximab on $\mathrm{T}$ lymphocyte function. Peripheral control of $\mathrm{T}$ lymphocyte activation and proliferation is largely dependent on cytokines (IL10, TGF $\beta$ ) secreted by regulatory $\mathrm{T}$ lymphocytes, and on induction of apoptosis (review in van Parijs and Abbas $^{96}$ ). T lymphocyte apoptosis results from the activation of death receptors that in turn activate intracellular caspases. Some apoptotic signals are transduced through alteration of the mitochondrial adenodine nucleotide translocator (and hence mitochondrial permeability), which is controlled by the ratio of two $\mathrm{Bcl}-2$ family proteins (that is, Bax and $\mathrm{Bcl}-2$ ), and this pathway has been shown to be particularly important in $\mathrm{T}$ lymphocytes. ${ }^{97-99}$ Two studies 
have recently demonstrated that mucosal $\mathrm{T}$ lymphocytes in Crohn's disease are resistant to induction of apoptosis by various signals and this is related to alteration of the $\mathrm{Bax} / \mathrm{Bcl} 2$ ratio. ${ }^{61}{ }^{62}$ We have investigated the effects of infliximab on apoptosis in CD3/CD28 stimulated Jurkat $\mathrm{T}$ lymphocytes, and observed a significant increase of the ratio of $\mathrm{Bax}$ (pro-apoptotic) and Bcl-2 (anti-apoptotic). As expected, this resulted in increased apoptosis of infliximab treated Jurkat cells, but only when the cells were previously activated. ${ }^{100}$ Hence, although the precise mechanism of apoptosis induction remains to be elucidated, these data suggested that infliximab, in addition to its antiinflammatory effects, may function as an "immunotoxin" that specifically targets activated $\mathrm{T}$ lymphocytes. Indeed, in infliximab treated patients with active Crohn's disease we found a rapid increase (24 hours after the infusion) of the number of apoptotic CD3+ lamina propria cells, without detectable changes of peripheral blood T lymphocyte phenotype or of markers of apoptosis. ${ }^{100}$ These observations would predict potential synergism with known inducers of $\mathrm{T}$ lymphocyte apoptosis (methotrexate), but antagonism with anti-apoptotic immunosuppressive drugs (for example, cyclosporine). Hence, further characterisation of the effects of infliximab on $\mathrm{T}$ lymphocyte function may be helpful in designing immunosuppressive combination treatments.

\section{Conclusions}

$\mathrm{TNF} \alpha$ targeting treatments in Crohn's disease have been tremendously boosted by the remarkable clinical efficacy of infliximab. However, different $\mathrm{TNF} \alpha$ targeting approaches have diverse biological activities, precluding extrapolation of the effects obtained with one reagent to other indications. The precise mechanism of action of infliximab in Crohn's disease remains to be elucidated, but in addition to the expected antiinflammatory activities, recent data strongly suggest the involvement of potent effects on $\mathrm{T}$ lymphocyte function. Further unravelling of these mechanisms may lead to novel therapeutic approaches and will aid in designing rational combination treatments. Finally, many questions remain to be answered, including the efficacy of repeated infusions, corticosteroid sparing effects, synergism or antagonism with other immunosuppressive drugs and long term disease modifying effects. Several of these questions are currently investigated in clinical trials.

1 Feeney M, Clegg A, Winwood P, Snook J. A case-control study of measles vaccination and inflammatory bowel disease. Lancet 1997;350:764-6.

2 Ekbom A, Daszak P, Kraaz W, Wakefield AJ. Crohn's disease after in-utero measles virus exposure [see comments]. Lancet 1996;348:515-17

3 Fisher NC, Yee L, Nightingale P, McEwan R, Gibson JA Measles virus serology in Crohn's disease. Gut 1997;41: 66-9.

4 Montgomery SM, Morris DL, Pounder RE, Wakefield AJ. Measles vaccination and inflammatory bowel disease [letter; comment]. Lancet 1997;350:1774.

5 Chadwick N, Bruce IJ, Schepelmann S, Pounder RE, Wakefield AJ. Measles virus RNA is not detected in inflammatory bowel disease using hybrid capture and reverse transcription followed by the polymerase chain reaction. J transcription followed by the

6 Thompson NP, Fleming DM, Pounder RE, Wakefield AJ. Crohn's disease, measles, and measles vaccination: a casecontrol failure [letter]. Lancet 1996;347:263.
7 Cellier C, De Beenhouwer H, Berger A, et al. Mycobacterium paratuberculosis and Mycobacterium avium
subsp. silvaticum DNA cannot be detected by PCR in Crohn's disease tissue. Gastroenterol Clin Biol 1998;22: 675-8.

8 Chiba M, Fukushima T, Horie Y, Iizuka M, Masamune O. No Mycobacterium paratuberculosis detected in intestinal tissue, including Peyer's patches and lymph follicles, of Crohn's disease. J Gastroenterol 1998;33:482-7.

9 Kreuzpaintner G, Das PK, Stronkhorst A, Slob AW, Strohmeyer G. Effect of intestinal resection on serum antibodies to the mycobacterial $45 / 48$ kilodalton doublet antigen in Crohn's disease. Gut 1995;37:361-6.

10 Engstrand L. Mycobacterium paratuberculosis and Crohn's disease. Scand J Infect Dis Suppl 1995; 98:27-9.

11 Dumonceau JM, Van Gossum A, Adler M, et al. No Mycobacterium paratuberculosis found in Crohn's disease using polymerase chain reaction. Dig Dis Sci 1996;41:421-6.

12 Russel MG, Stockbrugger RW. Epidemiology of inflammatory bowel disease: an update. Scand J Gastroenterol 1996; 31:417-27.

13 Russel MG, Dorant E, Volovics A, et al. High incidence of inflammatory bowel disease in The Netherlands: results of a prospective study. The South Limburg IBD Study Group. Dis Colon Rectum 1998;41:33-40.

14 Lapidus A, Bernell O, Hellers G, Lofberg R. Clinical course of colorectal Crohn's disease: a 35-year follow-up study of 507 patients. Gastroenterology 1998;114:1151-60.

15 Green JT, Rhodes J, Ragunath K, et al. Clinical status of ulcerative colitis in patients who smoke. Am J Gastroenterol 1998;93:1463-7

16 Russel MG, Nieman FH, Bergers JM, Stockbrugger RW. Cigarette smoking and quality of life in patients with inflammatory bowel disease. South Limburg IBD Study Group [see comments?. Eur J Gastroenterol Hepatol 1996; 8:1075-81.

17 Russel MG, Volovics A, Schoon EJ, et al. Inflammatory bowel disease: is there any relation between smoking status and disease presentation? European Collaborative IBD Study Group. Inflammatory Bowel Diseases 1998;4:182-6.

18 Munkholm P. Crohn's disease-occurrence, course and prognosis. An epidemiologic cohort-study. Dan Med Bull prognosis. An epidem

19 Munkholm P, Langholz E, Davidsen M, Binder V. Disease activity courses in a regional cohort of Crohn's disease patients. Scand J Gastroenterol 1995;30:699-706.

20 Hanauer SB. Inflammatory bowel disease [published erratum appears in N Engl J Med 1996;11;335:143]. N Engl J Med 1996;334:841-8.

21 Hanauer SB, Meyers S. Management of Crohn's disease in adults [see comments]. Am J Gastroenterol 1997;92: 559-66.

22 Brynskov J, Freund L, Rasmussen SN, et al. A placebocontrolled, double-blind, randomized trial of cyclosporine therapy in active chronic Crohn's disease [see comments]. therapy in active chronic Crohn's

23 Feagan BG, McDonald JW, Rochon J, et al. Low-dose cyclosporine for the treatment of Crohn's disease. The Canadian Crohn's Relapse Prevention Trial Investigators [see comments]. N Engl J Med 1994;330:1846-51.

24 Carp JM, Onuma E, Das K, Gottlieb AB. Intravenous cyclosporine therapy in the treatment of pyoderma gangrenosum secondary to Crohn's disease. Cutis 1997; 60:135-8.

25 Hinterleitner TA, Petritsch W, Aichbichler B, Fickert P, Ranner G, Krejs GJ. Combination of cyclosporine, azathioprine and prednisolone for perianal fistulas in Crohn's disprine and prednisolone for perianal fistul

26 Camma C, Giunta M, Rosselli M, Cottone M. Mesalamine in the maintenance treatment of Crohn's disease: a meta-analysis adjusted for confounding variables. Gastroenterology 1997;113:1465-73.

27 Munkholm P, Langholz E, Davidsen M, Binder V. Frequency of glucocorticoid resistance and dependency in Crohn's disease. Gut 1994;35:360-2.

28 Greenberg GR, Feagan BG, Martin F, et al. Oral budesonide for active Crohn's disease. Canadian Inflammatory Bowel Disease Study Group [see comments]. N Engl J Med 1994;331:836-41.

29 Rutgeerts P, Lofberg R, Malchow $\mathrm{H}$, et al. A comparison of budesonide with prednisolone for active Crohn's disease [see comments]. N Engl J Med 1994;331:842-5.

30 Thomsen OO, Cortot A, Jewell D, et al. A comparison of budesonide and mesalamine for active Crohn's disease. International Budesonide-Mesalamine Study Group [see comments]. N Engl J Med 1998;339:370-4.

31 Greenberg GR, Feagan BG, Martin F, et al. Oral budesonide as maintenance treatment for Crohn's disease: a placebo-controlled, dose-ranging study. Canadian Inflammatory Bowel Disease Study Group. Gastroenterology 1996;110:45-51.

32 Lofberg R, Rutgeerts P, Malchow H, et al. Budesonide prolongs time to relapse in ileal and ileocaecal Crohn's disease. A placebo controlled one year study. Gut 1996; 39:82-6.

33 Present DH, Meltzer SJ, Krumholz MP, Wolke A, Korelitz BI. 6-Mercaptopurine in the management of inflammatory bowel disease: short- and long-term toxicity. Ann Intern Med 1989;111:641-9.

34 Haber CJ, Meltzer SJ, Present DH, Korelitz BI. Nature and course of pancreatitis caused by 6 -mercaptopurine in the treatment of inflammatory bowel disease. Gastroenterology $1986 ; 91: 982-6$. 
35 Present DH, Korelitz BI, Wisch N, Glass JL, Sachar DB, Pasternack BS. Treatment of Crohn's disease with 6-mercaptopurine. A long-term, random
study. N Engl J Med 1980;302:981-7.

36 Pearson DC, May GR, Fick GH, Sutherland LR. Azathioprine and 6-mercaptopurine in Crohn disease. A metaanalysis. Ann Intern Med 1995;123:132-42.

37 Feagan BG. Methotrexate treatment for Crohn's disease. Inflammatory Bowel Diseases 1998;4:120-1.

38 Feagan BG, Rochon J, Fedorak RN, et al. Methotrexate for the treatment of Crohn's disease. The North American Crohn's Study Group Investigators [see comments]. N Engl J Med 1995;332:292-7.

39 Greenberger NJ, Miner PB. Is maintenance therapy effective in Crohn's disease? Lancet 1994;344:900-1.

40 Kim NK, Senagore AJ, Luchtefeld MA, et al. Long-term outcome after ileocecal resection for Crohn's disease. Am Surg 1997;63:627-33.

41 Rutgeerts P. Recurrence of Crohn's disease in the neoterminal ileum after ileal resection: is prevention therapy possible? Neth J Med 1994;45:60-4.

42 De Jong E, Van Dullemen HM, Slors JFM, Dekkers P, Van Deventer SJH, Tytgat GNJ. Correlation between early recurrence and reoperation after ileocolonic resection in
Crohn's disease: A prospective study. J Am Coll Surg 1996; Crohn's diseas

43 Watanabe $M$, Takaishi H, Hosoda Y, et al. CD4+ intestinal mucosal lymphocytes in the pathogenesis of Crohn's disease. J Gastroenterol 1995;30:73-5.

44 Cuvelier CA, Quatacker J, Mielants H, De Vos M, Veys E, Roels H. M cells are damaged and increased in number in inflamed human ileal mucosa. Eur J Morphol 1993;31:87infla

45 Elson CO. Advances in mucosal immunity. Drugs 1997;54: $13-14$.

46 Elson CO. The basis of current and future therapy for inflammatory bowel disease. Am J Med 1996;100:656-62.

47 Fiocchi C. The immune system in inflammatory bowel disease. Acta Gastroenterol Belg 1997;60:156-62.

48 Powrie F. T cells in inflammatory bowel disease: protective and pathogenic roles. Immunity 1995;3:171-4.

49 Powrie F, Mauze S, Coffman RL. CD4+ T-cells in the regulation of inflammatory responses in the intestine. Res Immunol 1997;148:576-81.

50 Fowell D, Powrie F, Saoudi A, Seddon B, Heath V, Mason D. The role of subsets of CD4+ T cells in autoimmunity. Ciba Foundation Symposium 1995;195:173-82; discussion $182-8$.

51 Powrie F, Coffman RL, Correa-Oliveira R. Transfer of CD4+ T cells to C.B-17 SCID mice: a model to study Th1 and Th2 cell differentiation and regulation in vivo. Res Immunol 1994;145:347-53.

52 Groux H, Bigler M, de Vries JE, Roncarolo MG Interleukin-10 induces a long-term antigen-specific anergic state in human CD4+ T cells [see comments]. J Exp Med 1996;184:19-29.

53 Groux H, O'Garra A, Bigler M, et al. A CD4+ T-cell subset inhibits antigen-specific T-cell responses and prevents colitis. Nature 1997;389:737-42.

54 Claesson $\mathrm{MH}$, Bregenholt S, Bonhagen $\mathrm{K}$, et al. Colitisinducing potency of CD4+ $\mathrm{T}$ cells in immunodeficient inducing potency of $\mathrm{CD} 4+\mathrm{T}$ cells in immunodeficient, adoptive hosts depends on their state of activation, IL-12 responsiveness, and CD

55 Bregenholt S, Claesson MH. Increased intracellular Th1 cytokines in scid mice with inflammatory bowel disease. Eur J Immunol 1998;28:379-89.

56 Monteleone G, Trapasso F, Parrello T, et al. Bioactive IL-18 expression is up-regulated in Crohn's disease. J Immunol 1999;163:143-7.

57 Pallone F, Monteleone G. Interleukin 12 and Th1 responses in inflammatory bowel disease. Gut 1998; 43:735-6.

58 Monteleone G, Biancone L, Marasco R, et al. Interleukin 12 is expressed and actively released by Crohn's disease intestinal lamina propria mononuclear cells. Gastroenterology 1997:112:1169-78.

59 Breese EJ, Michie CA, Nicholls SW, et al. Tumor necrosis factor alpha-producing cells in the intestinal mucosa of children with inflammatory bowel disease. Gastroenterology 1994;106:1455-66.

60 Breese E, MacDonald TT. TNF alpha secreting cells in normal and diseased human intestine. Adv Exp Med Biol 1995;371B:821-4.

61 Boirivant M, Marini M, Di Felice G, et al. Lamina propria T cells in Crohn's disease and other gastrointestinal inflammation show defective CD2 pathway-induced apoptosis. mation show defective CD2 pathway-
Gastroenterology 1999;116:557-65.

62 Ina K, Itoh J, Fukushima K, et al. Resistance of Crohn's disease T cells to multiple apoptotic signals is associated with a bcl-2/Bax mucosal imbalance. J Imunol 1999;163:108190 .

63 Rutgeerts P, Goboes K, Peeters M, et al. Effect of faecal stream diversion on recurrence of Crohn's disease in the neoterminal ileum [see comments]. Lancet 1991;338: $771-4$.

64 D'Haens GR, Geboes K, Peeters M, Baert F, Penninckx F, Rutgeerts P. Early lesions of recurrent Crohn's disease caused by infusion of intestinal contents in excluded ileum [see comments]. Gastroenterology 1998;114:262-7.

65 Neurath MF, Pettersson S. Predominant role of Nf-kappa-B P65 in the pathogenesis of chronic intestinal inflammation. Immunobiology 1997;198:91-8.
66 Moss ML, Jin SLC, Becherer JD, et al. Structural features and biochemical properties of Tnf-alpha converting enzyme (Tace). J Neuroimmunol 1997;72:127-9.

67 Black RA, Durie FH, Otten-Evans C, et al. Relaxed specificity of matrix metalloproteinases (MMPS) and TIMP insensitivity of tumor necrosis factor-alpha (TNF-alpha) production suggest the major TNF-alpha converting
enzyme is not an MMP. Biochem Biophys Res Commun 1996;225:400-5.

68 Gearing AJ, Beckett P, Christodoulou M, et al. Matrix metalloproteinases and processing of pro-TNF-alpha. J Leuk Biol 1995;57:774-7.

69 Crowe PD, Walter BN, Mohler KM, Otten-Evans C, Black RA, Ware CF. A metalloprotease inhibitor blocks shedding of the $80-\mathrm{kD}$ TNF receptor and TNF processing in T lymphocytes. J Exp Med 1995;181:1205-10.

70 van Montfrans C, van de Ende A, Fedorak RN, et al. Antiand proinflammatory effects of interleukin-10 in mild to moderate Crohn's disease. Gastroenterology 1999;116: A777, G3370.

71 Tilg H, Kaser A, Propst A, et al. Recombinant human interleukin-10 (rHuIL-10) therapy in steroid-refractory chronic active Crohn's disease (CACD): induction of neopterin, a degradation product of the pteridine pathway regulated by Interferon-gamma. Gastroenterology 1998; 114:A1100, G4500

72 Fedorak RN, Gangl A, Elson CO, et al. Safety, tolerance, and efficacy of multiple doses of subcutaneous interleukin-10 in mild to moderate active Crohn's siseases. Digestive Disease Week abstract book, 1998.

73 Nikolaus S, Meinzer U, Gasche C, et al. Clinical response to subcutaneous RHUIL-10 in chronic active, steroid refractory Crohn's disease is strongly associated with an increase of IKBA and inhibition of mucosal NFKB P65 activation. Gastroenterology 1999;116:A784, G3402.

74 van der Poll T, Coyle SM, Barbosa K, Braxton CC, Lowry SF. Epinephrine inhibits tumor necrosis factor-alpha and potentiates interleukin 10 production during human endotoxemia. J Clin Invest 1996;97:713-19.

75 Van der Poll T, Lowry SF. Epinephrine inhibits endotoxininduced IL-1 beta production: roles of tumor necrosis factor-alpha and IL-10. Am J Physiol 1997;273:R1885-90.

76 Han J, Thompson P, Beutler B. Dexamethasone and pentoxifylline inhibit endotoxin-induced cachectin/tumor necrosis factor synthesis at separate points in the signaling pathway. J Exp Med 1990;172:391-4.

77 Levi M, Ten Cate H, Bauer KA, et al. Inhibition of endotoxin-induced activation of coagulation and fibrinolysis by pentoxifylline or by a monoclonal anti-tissue factor antibody in chimpanzees. J Clin Invest 1994;93:114-20.

78 McHugh SM, Rowland TL. Thalidomide and derivatives immunological investigations of tumour necrosis factoralpha (TNF-alpha) inhibition suggest drugs capable of selective gene regulation [Review]. Clin Exp Immunol 1997:110:151-4.

79 Marriott JB. Biologicals and immunologicals. TNF-alpha antagonists: monoclonal antibodies, soluble receptors, thalidomide and other novel approaches. Expert Opinion on Investigational Drugs 1997;6:1105-8.

80 Muller GW, Shire MG, Wong LM, et al. Thalidomide analogs and PDE4 inhibition. Bioorg Med Chem Lett 1998;8: 2669-74.

81 Black RA, Rauch CT, Kozlosky CJ, et al. A metalloproteinase disintegrin that releases tumour-necrosis factor-alpha from cells. Nature 1997;385:729-33.

82 Moss ML, Jin SL, Becherer JD, et al. Structural features and biochemical properties of TNF-alpha converting enzyme (TACE). J Neuroimmunol 1997;72:127-9.

83 Bauditz J, Ruckert Y, Raedler A, Nikolaus S, Lochs H, Schreiber $S$. Tumour necrosis factor inhibition by oxpentifylline and intestinal inflammation in Crohn's disease [letter; comment]. Lancet 1995;345:1445.

84 Bauditz J, Haemling J, Ortner M, Lochs H, Raedler A, Schreiber S. Treatment with tumour necrosis factor inhibitor oxpentifylline does not improve corticosteroid dependent chronic active Crohn's disease [see comments]. Gut 1997; 40:470-4

85 Neurath MF, Becker C, Barbulescu K. Role of NF-kappa B in immune and inflammato

86 Derkx B, Taminiau J, Radema S, et al. Tumour-necrosisfactor antibody treatment in Crohn's disease [letter] [see comments]. Lancet 1993;342:173-4.

87 Van Dullemen HM, Van Deventer SJH, Hommes DW, et al. Treatment of Crohn's disease with anti-tumor necrosis factor chimeric monoclonal antibody (cA2). Gastroenterology 1995;109:129-35.

88 Van Dullemen HM, Wolbink GJ, Wever PC, et al. Reduction of circulating secretory phospholipase A(2) levels by anti-tumor necrosis factor chimeric monoclonal antibody in patients with severe Crohn's disease - Relation between tumor necrosis factor and secretory phospholipase $\mathrm{A}(2)$ in healthy humans and in active Crohn's disease. Scand J Gastroenterol 1998;33:1094-8.

89 Targan SR, Hanauer SB, van Deventer SJ, et al. A short-term study of chimeric monoclonal antibody cA2 to tumor necrosis factor alpha for Crohn's disease. Crohn's disease cA2 Study Group. N Engl J Med 1997;337:102935 .

90 Rutgeerts P, D'Haens G, Van Deventer SJ, et al. Retreatment with anti-TNF chimeric monoclonal antibody (cA2) effectively maintains cA2-induced remission in Crohn's disease, Digestive Disease Week abstract book, 1997. Vol. DDW abstract book. 
91 D'Haens G, Van Deventer S, Van Hogezand R, et al. Endoscopic and histological healing with infliximab anti-tumor necrosis factor antibodies in Crohn's disease: A Europe
multicenter trial. Gastroenterology 1999;116:1029-34.

multicenter trial. Gastroenterology 1999;116:1029-34.
92 Present DH, Rutgeerts P, Targan S, et al. Infliximab for the treatment of fistulas in patients with Crohn's disease. N Engl J Med 1999;340:1398-405.

93 van Dullemen HM, de Jong E, Slors F, Tytgat GN, van Deventer SJ. Treatment of therapy-resistant perineal metastatic Crohn's disease after proctectomy using anti-tumor necrosis factor chimeric monoclonal antibody, cA2: report of two cases. Dis Colon Rectum 1998;41:98-102.

94 Stack WA, Mann SD, Roy AJ, et al. Randomised controlled trial of CDP571 antibody to tumour necrosis factor-alpha in Crohn's disease [see comments]. Lancet 1997;349:521-4.

95 Van Deventer SJ. Tumour necrosis factor and Crohn's disease [see comments]. Gut 1997;40:443-8.
96 Van Parijs L, Abbas AK. Homeostasis and self-tolerance in the immune system: turning lymphocytes off. Science 1998;280:243-8.

97 Marzo I, Brenner C, Zamzami N, et al. Bax and adenine nucleotide translocator cooperate in the mitochondrial control of apoptosis. Science 1998;281:2027-31.

98 Green D, Kroemer G. The central executioners of apoptosis: caspases or mitochondria? Trends in Cell Biology 1998;8:267-71.

99 Hirsch T, Susin SA, Marzo I, Marchetti P, Zamzami N, Kroemer G. Mitochondrial permeability transition in apoptosis and necrosis. Cell Biol Toxicol 1998;14:141-5.

100 Ten Hove T, van Deventer SJH. Anti-TNF antibody Ca2 induces apoptosis in CD3/CD28 stimulated Jurkat cells: A; potent immunomodulatory mechnism. Gastroenterology 1999;116:A739. 